\title{
OPTIMAL CEO INCENTIVE CONTRACTS: A PROSPECT THEORY EXPLANATION
}

\author{
Joshua R. Aaron \\ Middle Tennessee State University • Murfreesboro, TN \\ Michael L. Harris \\ East Carolina University • Greenville, NC \\ William C. McDowell \\ Middle Tennessee State University • Murfreesboro, TN \\ Brandon N. Cline \\ Mississippi State University • Starkville, MS
}

\begin{abstract}
This study examines the relationship between CEO incentive-based compensation and firm performance, based on the role of prospect theory in executive compensation. Our results indicate that moderate levels of performance-based CEO compensation are generally optimal. When an executive's total compensation package is based more on firm performance there is often a level of higher returns, but to a point of diminishing return. Our findings suggest that boards must clearly communicate with CEOs to determine the most appropriate levels of incentive-based compensation. Additional managerial and theoretical implications are offered, as well as avenues for future research.
\end{abstract}

\section{INTRODUCTION}

The proper structuring of executive compensation contracts has been the subject of much debate in the finance (Jensen \& Meckling, 1976; Jensen \& Murphy, 1990) and management literatures (Wright, Ferris, Sarin, \& Awasthi, 1996; Sundaramurthy, Rhoades, \& Rechner, 2005). This debate has largely been grounded in agency theory, which suggests that executives should be given equity stakes in their companies in order to properly align their interests with shareholders' interests. Thus, equity ownership is assumed to have a positive and direct effect on firm performance because aligning the risk preferences of executives and shareholders is the key to aligning their interests. The results, however, have been inconclusive. It is possible that the reliance on agency theory and the assumption of a positive linear relationship between ownership and performance has been the cause of confusion. Prospect theory (Kahneman \& Tversky, 1979), however, may provide a better expla- 
nation for how individuals actually make decisions regarding a bundle of financial resources. Prospect theory is derived from offering individuals prospects (decision sets) with various payoffs and observing their decision making process and outcomes. Prospect theory is presented as an alternative to utility theory assumptions that serve as the foundation for agency theory. We believe the application of prospect theory can help explain that the ownership-performance relationship is actually nonlinear (concave).

The purpose of this study is to apply prospect theory to incentive-based CEO compensation in an attempt to clarify conflicting findings in this area. Specifically, this study examines the relationship between CEO incentive-based compensation and subsequent firm performance in a sample containing 18,540 CEO observations from 1992-2004.

\section{LITERATURE REVIEW}

\section{Ownership - Risk Relationship}

By properly structuring an incentive contract, firms can motivate corporate insiders to engage in additional corporate risk taking while developing growth opportunities (Jensen \& Meckling, 1976; Jensen \& Murphy, 1990). In order to more closely merge the interests of corporate insiders and shareholders, and thus reduce the potential for agency conflict, insiders have often been provided with an equity interest in firms. Typically, firms allow discounted stock purchase programs or grant stock options in an attempt to reduce agency conflict. The presumption underlying these programs has been that there is a positive relationship between insider equity ownership and corporate risk taking (Wright et al., 1996). Eisenmann (2002) does find that CEOs given equity ownership are more risk-seeking while those with no ownership are risk-averse.

However, other studies have shown that this increase in risk-taking behaviors will eventually diminish at higher levels of equity ownership. Wright et al. (2007) find that at low to moderate values of managerial stock ownership, risk-increasing decisions predominate. However, at substantial executive equity values, risk-reducing decisions are motivated. Similarly, Wright et al. (1996) find a nonlinear (concave) relationship between insider equity ownership and firm risk-taking. Despite shareholders preference for growth-oriented risk taking, there are instances where executives may desire to reduce risk-taking behavior. They suggest two explanations concerning why equity ownership programs do not give corporate insiders clear in- 
centives to enhance firm performance through growth-oriented risk taking. These include financial costs as well as personal costs for the executive (Wright et al., 1996).

First, regarding the financial costs, executives may not increase corporate risk taking as they obtain higher levels of equity ownership because of the potential for wealth "undiversification." More specifically, if a substantial component of an executive's wealth is concentrated in a single investment, the executive may not find it personally desirable to increase risk taking in regards to that investment (Wright et al., 1996). High levels of equity ownership in the firm serve to decrease the executive's portfolio diversification and may cause them to adopt a suboptimal conservative strategy due to the executive having so much "on the line".

Second, regarding the personal costs for the executive, "they may reduce corporate risk taking in order to lower the personal costs of such decisions. Included among these costs would be the potential loss of employment, the extra effort required to master new technologies or manage new ventures, and the anxieties inherent in higher-risk corporate undertakings" (Wright et al. 1996 p. 443). Corporate insiders may make decisions based upon an attempt to minimize personal stress generated by a particular firm strategy. This practice could result in the selection of a set of non-value-maximizing projects for a firm. Wright et al. (1996) do not establish a relationship between ownership and firm performance although they suggest that future research should explore the issue.

\section{Ownership - Performance Relationship}

Wright et al. (1996) state the nature of a firm's risk-taking behavior can significantly affect corporate performance, but they do not attempt to establish a link directly from insider equity ownership to firm performance. Subsequently, several researchers have attempted to expand on this research area and establish this important link. McGuire and Matta (2003), however, find that the exercise of stock options has no impact on the levels of CEO equity and no relationship with subsequent firm performance. Thus, the decision to exercise stock options appears to reflect riskbalancing concerns rather than expectations for future performance.

Empirical evidence regarding the impact of executive and institutional ownership, however, is quite mixed. For example, Tsetsekos and DeFusco (1990) found no significant relationship between executive ownership and firm performance while Mehran (1995) and Hambrick and Jackson (2000) each found a direct, positive relationship, and others such as McConnell and Servaes (1990) found a non-linear relationship. In an attempt to reconcile these contradictory findings, Sundaramurthy 
et al. (2005) performed a meta-analysis, and their results indicated that there is no substantive relationship between ownership and firm performance.

In an effort to explain these conflicting problems, it is proposed that overreliance on agency theory has been the cause for much confusion in literature. The application of agency theory leads to an assumption of a positive linear relationship between ownership and firm performance. The next section will explain the basic tenants of agency theory and outline the problems associated with attempting to utilize this theory to explain the ownership-performance relationship.

\section{The Agency Theory Problem}

In an effort to examine the ownership-performance relationship through the lens of existing theory, agency theory should be examined. Agency theory (Eisenhardt, 1989) is directed at explaining agency relationships, where one party (principal) delegates work to another party (agent) who actually performs the work and addresses two main problems within the organization. The first is that of shirking which occurs because the goals or desires of the principal and agent often differ and it is difficult for the principal to monitor agent activity. The second is a problem of risk sharing and occurs when the principal and agent have different attitudes toward risk. In this case, the agent may favor a different course of action than the principal. Agency theory is concerned with solving this problem by determining the best way to govern the principal-agent relationship given a different set of assumptions, attitudes, and goals (Eisenhardt, 1989).

The CEO-shareholder relationship is a very complex version of an agency problem. Based on agency theory, firms may use their executive compensation plans to properly align the interests of corporate executives (agents) with those of the shareholders (Mengistae \& Lixin, 2004). Alignment of incentives is difficult due to uncertainty about the relationship between agent actions and desired outcomes. Additionally, shareholders and CEOs have varying amounts of information about the firm. It is costly for shareholders to monitor CEO behavior because so many of their actions are hard for shareholders to detect (Chaudri, 2003).

Since actions are imperfectly observable, performance measures must accommodate relative weightings of managerial actions and exogenous factors that affect desired outcomes. Firms need to decide the appropriate balance between rewarding individual performance and rewarding firm performance (Chaudri, 2003). Agency theory predicts that the optimal contracts depend not only on firm-specific factors but also on CEO-specific factors as well (Kim, 2004). Kim suggests that 
firm-specific factors such as riskiness, size, growth, and governance structure are important but not the only concern. Firms should also consider CEO-specific factors, such as CEO ability and experience, and alter the pay-performance sensitivity when a CEO leaves and is replaced.

The use of agency theory to explain the ownership-performance relationship has, however, been called into question (Buck et al., 2003). Dalton et al. (2003) conducted a meta-analysis of relevant ownership-performance studies and found little support for agency theory, calling for a new lens to be applied. Despite this, the basic agency problem certainly exists and the alignment of interests is important. Compensation should be, at least partially, tied to performance, but research is lacking a prescriptive suggestion in terms of how much compensation to tie to performance. Is more necessarily better? Is there such a thing as too much?

Why has the agency theory lens been so inconclusive? Noorderhaven (1992) notes agency theory relies on an individual utility maximization assumption (utility theory). We believe that utility maximization assumptions are fundamentally flawed in terms of explaining the way people make decisions. In the following section, prospect theory is offered as an alternative explanation to individual decision making and distinguish it from utility theory assumptions.

\section{Prospect Theory and Executive Compensation}

Prospect theory (Kahneman \& Tversky, 1979) challenges the assumptions of utility theory in terms of the ways individuals make decisions in three primary ways. First, utility theory evaluates utility from the final states of wealth, including wealth from the prospect and other existing assets, whereas prospect theory evaluates the value of a prospect from a change in wealth due to a prospect (Kahneman \& Tversky, 1979). Second, utility theory uses stated probabilities to find the expected utility, where expected utility is the summation of utilities from each possible outcome, weighted by the probability of occurrence for each potential outcome. Prospect theory, however, uses decision weights in its value function. The decision weighting function proposed by Kahneman and Tversky (1979) has the decision weights different from the states' probabilities, except for extreme outcomes. Extremely low probability events beyond a certain benchmark are assigned a zero probability of occurrence, whereas those with an extremely high probability of occurrence are treated with certainty. Third, utility theory assumes that investors are risk averse, risk neutral or risk seeking, but the same person cannot simultaneously exhibit risk aversion, risk neutrality and risk-seeking characteristics. On the other hand, prospect theory 
predicts that investors would be risk averse in gains and risk seeking in losses, regardless of their level of wealth. The value function of prospect theory follows an S-curve with a gentle slope for gains and a much steeper slope for losses suggesting that investors would suffer a much greater disutility in a loss than they would enjoy utility from a gain of the same absolute magnitude (Ding et al. 2004).

Prospect theory offers an attractive alternative to the assumptions of utility theory in terms of individual decision making among several prospects. In this context, different compensation packages represent different prospects from which to choose. In the following section, we differentiate prospect theory from utility theory and apply prospect theory to the context of executive compensation.

There are four primary ways that prospect theory informs the issue of executive compensation. First, prospect theory holds that people overweigh outcomes that are considered certain relative to outcomes that are merely probable. When an executive has a large amount of options relative to total compensation and those options are "in the money", the executive may choose to "maintain the status quo" and try to hold on to that amount of money. An "in the money" option refers to an option where the underlying stock price is trading at a price above the strike price of the option. For example, if an option were struck at $\$ 50$, a stock trading at $\$ 70$ would be considered "in the money" while a stock trading at $\$ 30$ would be considered "out of the money" or "underwater." In essence, the executive will view the current level as a certain gain and any additional gains as merely probable. In this case, the executive will adopt a defensive strategy designed to maintain the current stock price until the vesting date of the options. The interests of the shareholders are clearly not aligned with those of the executives.

Second, the converse also results in incentives being misaligned. If the options are out of the money, there are two alternatives for executives that shareholders would not prefer. First, the executives may become "too risky" in terms of firm strategy in an attempt to rescue the option value before the vesting date. Brunnermeir (2004) suggests that individuals exhibit a diminishing sensitivity to losses. A monetary loss at the breakeven point will lead to a far higher decrease in utility than an equal monetary loss from a deep loss position. People become more willing to take on risk after suffering a substantial loss. More specifically, they become less risk averse or even risk seeking over losses. This translates into a value function that is less concave or even convex in the loss region. Brunnermeir also claims that individuals' preferences exhibit loss aversion. Therefore, they are much more responsive to losses than to gains. A decrease in income by $\$ X$ results in a much higher utility loss than the utility gain associated with an increase in income by $\$ X$. 
In other words, the value function is steeper in the loss region than in the gain region. Second, the executives may become disheartened and think that the option becoming "in the money" is hopeless. Here, the executive may not continue the pursuit of better financial performance of the firm, as the shareholders would expect.

Third, prospect theory also holds that an individual's reference point may shift (Kahneman \& Tversky, 1979). Risk preferences depend highly on the individual's reference income level. The reference income plays an important role in determining whether a prospect will be accepted or not. The reference income level refers to the level to which an individual will compare future states. For example, a person that started a job making $\$ 50,000$ per year and now makes $\$ 100,000$ per year will see a drop to $\$ 90,000$ as a $\$ 10,000$ loss and not simply a reduction of a gain. Therefore, it is useful to consider losses and gains with respect to this reference income level rather than to the absolute income level (Brunnermeir, 2004). This further explains the desire to maintain status quo when options are "in the money." Executives who have options "in the money" may change their reference point to the current value of the stock and see even a small drop in stock price as a direct loss rather than a reduction in gain. We have already stated above that an individual's utility functions are steeper for losses than gains. In this case, the executive will likely minimize the risk of the firm by adopting a defensive firm strategy because firm risk is exactly equivalent to the risk of the executive's personal wealth. Levy and Levy (2004) claim that individuals make decisions based on change of wealth rather than the total wealth, which is in direct contradiction to expected utility theory. Thus, risk aversion does not prevail globally. Individuals become risk seeking regarding losses. Additionally, individuals distort objective probabilities and subjectively transform them in a systematic way so that even a small probability for a loss will have a profound impact on executive decision-making.

Finally, prospect theory also helps to explain the threat of a top manager's desire to manage earnings. Shen and Chih (2005) specifically applied prospect theory to the incentives of banks to manage earnings. The theory suggests that individuals derive values from gains and losses with respect to a reference point, rather than being from absolute levels of wealth. It also suggests that individuals' value functions are concave in gains and convex in losses (S-shape). Thus, for a given increase in wealth, the increase in value is greatest when the wealth of the individual increases from a loss to a gain relative to a reference point. If the preferences of the stakeholders are consistent with the prospect theory, then the manager has an incentive to report earnings that exceed the threshold, or the reference point, such as zero earnings levels or zero earnings changes, to obtain more rewards. The S-shape prospect 
theory suggests that the decision maker will be risk averse above the reference point and risk seeking below it. Here, executives have incentive to manage earnings in order to avoid earnings decreases. The same could certainly be true for an executive whose compensation is tied to the performance of the firm.

\section{HYPOTHESIS}

Based on the findings of Wright et al. (1996) of a nonlinear relationship between equity ownership and risk taking behaviors as well as the insights of prospect theory, it is expected that the relationship between ownership and firm performance will be nonlinear (concave). Thus, this paper extends previous empirical research in hypothesizing that moderate levels of CEO pay for performance will result in the highest returns.

H1: The relationship between the percentage of incentive-based CEO compensation and firm performance will be nonlinear (concave).

\section{METHODOLOGY}

\section{Sample}

The dataset used in this study is drawn from Standard and Poor's Execucomp. Execucomp is an executive compensation database consisting of executive compensation data reported beginning in 1992 to 2004. The dataset reports more than 100 financial variables from 24,170 executives at 2,540 firms from 1992-2004.

The original dataset contained 19,167 CEO observations ranging from 19922004. We chose to examine CEOs only to avoid confounding the results with multiple observations tied to the same performance item. We deleted the observations that were missing data on one of our focal variables and 19,029 remained. Finally, we deleted the observations that had stock prices of less than one dollar because they tend to have highly abnormal returns. The final sample contains 18,540 observations. Those observations were sorted by percentage of performance-based compensation and then divided into quintiles, each with 3,708 observations. The purpose of using quintiles was to observe the pattern of the data and subsequently test for mean differences among them. Quintile 1 contains the lowest 3,708 observations in terms of percentage performance-based compensation while quintile 5 contains the highest 3,708 observations. Each quintile had some missing performance data and thus we lost some observations. The number of observations ranges from 3,496 in quin- 
tile 1 to 3,574 in quintile 4 . The cutoffs for the quintiles (in terms of percentage of incentive-based compensation) are as follows: Q1 0\%; Q2 1\%-34\%; Q3 35\%-52\%; Q4 53\%-71\%; Q5 72\%-100\%.

\section{Measures, Data and Analysis}

We define the independent variable as the percentage of incentive-based compensation relative to the overall compensation for the CEO. Previous literature has focused on the percentage of insider ownership (Morck et al., 1988; Wright et al., 1996) or amount of a rise in performance that should be shared with insiders (Jensen $\&$ Murphy, 1990). Here, we choose to examine the percentage of incentive-based compensation to total compensation because we look at CEOs only. CEOs will likely make their choices in terms of risk-preference based on the actual dollar value they have "on the line" as a percentage of their overall pay rather than basing their preferences on the percentage of the firm they own. Incentive-based compensation includes the Black-Scholes option value plus the value of the restricted stock grants. Total compensation includes performance-based compensation plus salary and bonus. The dependent variable for the study is firm performance. We assessed firm performance as the CRSP (Center for Research in Security Prices) equally weighted mean cumulative abnormal return. Cumulative abnormal returns (CAR) are the returns for a specific firm for one year, two years, etc. following the fiscal year end as compared to the market as a whole. Essentially, CAR are the returns the firm received net of the return they "should have" received simply from being a publicly traded firm operating in this particular industry during the time period examined.

\section{RESULTS}

To estimate abnormal performance, we conduct an event study employing a CRSP market model. An event study uses the EVENTUS software through WRDS (Wharton Research Data Services) to determine the impact of a precipitating event (occurring on the "event date") measured in terms of the market reaction to it. The use of the CRSP market model (noted below) allows multiple and overlapping option grants for CEOs to be aggregated to one date. Thus, it was possible to examine the returns around the specific date. Fiscal year end for a firm serves as the focal date because we do not have the date of the option grant and there would be some CEOs with several grant dates in one year. Mean cumulative abnormal returns were used to examine the performance around the focal date.

The CRSP market model is stated as: 


$$
R_{j t}=\alpha+\beta_{j} R_{m t}+\varepsilon_{j t}
$$

where $R_{j t}$ is the rate of return of the $j^{\text {th }}$ firm in month $t ; R_{m t}$ is the rate of return on the market index in month $t$; and $\beta_{j}$ is a parameter that measures the sensitivity of $R_{j t}$ to the market index.

Bae and Sami (2002) in their investigation of the impact of environmental liabilities on the reliability of accounting information control for market expectation, opportunities for growth, industry membership, firm size, and firm risk. The use of the CRSP market model allows control for market expectation, industry membership, and firm risk as well as stock market fluctuations. Market expectation and firm risk are controlled because the market model first calculates what a "normal" return should be in order to calculate the "abnormal" return. The normal return is itself the market expectation and takes the inherent risk of the firm into account. Stock market fluctuations are controlled because the data runs from 1992-2004 and each year's returns are given equal weight. Therefore, to the extent that the time period 19922004 approximates an "average" of the stock market, our results will be free from a stock market bias.

Figure 1 displays the results of the association study. The mean abnormal return for each of the first five years was tested after the event date. Figure 1 represents the market-adjusted mean cumulative abnormal return. Cumulative abnormal return means that the return in year 2 includes the return over the 2-year period, not just year 2 alone. The pattern of the data displayed in Figure 1 appears to suggest the underlying relationship is non-linear. The pattern for each of the first three years appear to follow a nonlinear concave curve with a rise from quintile 1 to quintile 2 and from quintile 2 to quintile 3 followed by a subsequent drop from quintile 3 to quintile 4 and from quintile 4 to quintile 5 . The four and five year returns do not follow the same pattern exactly because of a drop from quintile 1 to quintile 2 , but all data points from quintile 2 through quintile 5 are consistent with expectations and with the results from years 1-3. These results indicate that basing more of an executive's total compensation on firm performance is linked with higher abnormal returns, but to a certain diminishing point. 


\section{Figure 1}

Market-Adjusted Cumulative Abnormal Returns

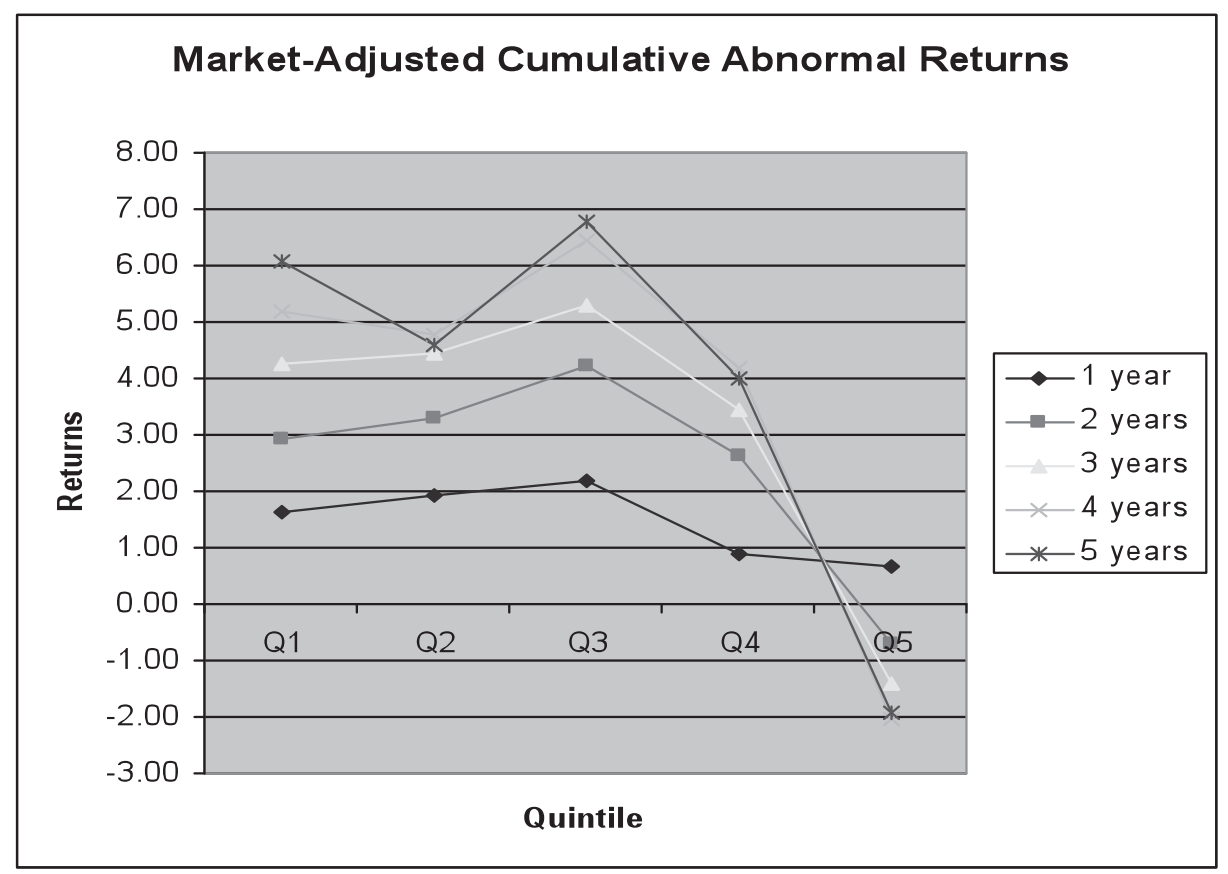

Two-sample t-tests were used to examine the differences between quintile 1 , quintile 3 and quintile 5 . All means are significantly different from each other at the $\mathrm{p}<.001$ level, providing evidence that there is a significant rise from quintile 1 to quintile 3 followed by a subsequent significant fall from quintile 3 to quintile 5 for each curve. We ran analyses for each year separately. Each of the first two years has the exact same pattern as the curves in Figure 1. Years 3, 4 and 5 do not have as smooth of a curve, but each of those years shows a dramatic drop from Quintile 3 to Quintile 5, providing further evidence against a strictly positive relationship.

\section{Regression Results}

In order to test the curvilinear nature of the data, we ran listwise linear regressions on CAR measured in five different points in time. The dependent variable is cumulative abnormal return for 12 months, 24 months, 36 months, 48 months and 60 months. First, the controls in Model 1 were entered: net sales, total compensation of the CEO and number of employees. In Model 2, focal variable of percentage of 
incentive-based compensation was entered to obtain an r-square assuming a linear relationship. In Model 3, the squared term of percentage of incentive-based compensation was entered to see if the curvilinear assumption added any explanatory power. The results are remarkably consistent regardless of the number of months used as the dependent variable. In each case, the controls explain a very minimal amount of variance (.004 or less). All r-squares for the linear and curvilinear models are significant at the $\mathrm{p}<.001$ level. In each year, the curvilinear model explains more than twice as much (average of .026 versus .012) variance in cumulative abnormal return than does the linear model. Tables one through five display these results.

Table 1

1-year Cumulative Abnormal Returns

\begin{tabular}{|c|c|c|c|}
\hline & Model (1) & Model (2) & Model (3) \\
\hline \multirow{2}{*}{ Constant } & .007 & .031 & -.004 \\
\hline & $(.160)$ & (.674) & $(-.094)$ \\
\hline \multicolumn{4}{|l|}{ Control variables } \\
\hline \multirow{2}{*}{ Net Sales } & .013 & .015 & .012 \\
\hline & $(1.101)$ & $(1.306)$ & $(1.064)$ \\
\hline \multirow{2}{*}{ Number of Employees } & .015 & .016 & .014 \\
\hline & $(1.296)$ & $(1.345)$ & $(1.186)$ \\
\hline \multirow{2}{*}{ Total Compensation } & $-.090^{\star \star \star}$ & $-.078^{\star \star \star}$ & $-.059^{\star \star \star}$ \\
\hline & $(-11.217)$ & $(-9.312)$ & $(-6.869)$ \\
\hline \multicolumn{4}{|l|}{ Compensation variables } \\
\hline \multirow{2}{*}{ Percent Incentive Compensation } & & $-.042^{\star \star \star}$ & $.169^{\star \star \star}$ \\
\hline & & $(-5.117)$ & $(6.485)$ \\
\hline \multirow{2}{*}{$\begin{array}{l}\text { Percent Incentive Compensa- } \\
\text { tion } \wedge 2\end{array}$} & & & $-.229^{\star \star \star}$ \\
\hline & & & $(-8.551)$ \\
\hline \multicolumn{4}{|l|}{ Model significance } \\
\hline R-Squared & $.011^{\star \star \star}$ & $.013^{\star \star \star}$ & $.017^{\star \star \star}$ \\
\hline Adjusted R-Squared & $.010^{\star \star *}$ & $.012^{\star \star \star}$ & $.016^{\star \star \star}$ \\
\hline Change in R-Squared & & $.002^{\star \star \star}$ & $.004^{\star \star \star}$ \\
\hline
\end{tabular}

${ }^{\star} p<.05$ level, ${ }^{* \star} p<.01$ level, ${ }^{* \star *} p<.001$ level $n=18,540$

top line $=$ standardized beta coefficients (constant is unstandardized)

bottom line $=$ t-statistics (in parentheses) 
Table 2

2-year Cumulative Abnormal Returns

\begin{tabular}{|c|c|c|c|}
\hline & Model (1) & Model (2) & Model (3) \\
\hline \multirow{2}{*}{ Constant } & .018 & .066 & -.007 \\
\hline & $(.244)$ & $(.913)$ & $(-.092)$ \\
\hline \multicolumn{4}{|l|}{ Control variables } \\
\hline \multirow{2}{*}{ Net Sales } & .022 & $.025^{\star}$ & .021 \\
\hline & $(1.855)$ & $(2.124)$ & $(1.810)$ \\
\hline \multirow{2}{*}{ Number of Employees } & .018 & .019 & .016 \\
\hline & $(1.549)$ & $(1.614)$ & $(1.408)$ \\
\hline \multirow{2}{*}{ Total Compensation } & $-.116^{\star \star \star}$ & $-.100^{\star \star \star}$ & $-.076^{\star \star \star}$ \\
\hline & $(-14.480)$ & $(-12.013)$ & $(-8.836)$ \\
\hline \multicolumn{4}{|l|}{ Compensation variables } \\
\hline \multirow{2}{*}{ Percent Incentive Compensation } & & $-.055^{\star \star \star}$ & $.221^{\star \star \star}$ \\
\hline & & $(-6.659)$ & $(8.512)$ \\
\hline \multirow{2}{*}{$\begin{array}{l}\text { Percent Incentive Compensa- } \\
\text { tion } \wedge 2\end{array}$} & & & $-.298^{\star \star \star}$ \\
\hline & & & $(-11.208)$ \\
\hline \multicolumn{4}{|l|}{ Model significance } \\
\hline R-Squared & $.020^{\star \star \star}$ & $.023^{\star \star \star}$ & $.030^{\star * \star}$ \\
\hline Adjusted R-Squared & $.019^{\star \star \star}$ & $.022^{* \star *}$ & $.029^{\star \star \star}$ \\
\hline Change in R-Squared & & $.003^{* \star \star}$ & $.008^{* * *}$ \\
\hline
\end{tabular}

${ }^{\star} p<.05$ level, ${ }^{\star \star} p<.01$ level, ${ }^{* \star \star} p<.001$ level $n=18,540$

top line $=$ standardized beta coefficients (constant is unstandardized)

bottom line $=$ t-statistics (in parentheses) 
Table 3

\section{3-year Cumulative Abnormal Returns}

\begin{tabular}{|c|c|c|c|}
\hline & Model (1) & Model (2) & Model (3) \\
\hline \multirow{2}{*}{ Constant } & .035 & .111 & .002 \\
\hline & (.375) & $(1.182)$ & $(.020)$ \\
\hline \multicolumn{4}{|l|}{ Control variables } \\
\hline \multirow{2}{*}{ Net Sales } & .021 & $.025^{*}$ & .021 \\
\hline & $(1.809)$ & $(2.135)$ & $(1.773)$ \\
\hline \multirow{2}{*}{ Number of Employees } & .022 & $.023^{*}$ & .020 \\
\hline & $(1.907)$ & $(1.987)$ & $(1.752)$ \\
\hline \multirow{2}{*}{ Total Compensation } & $-.126^{\star \star \star}$ & $-.107^{\star \star \star}$ & $-.079^{\star \star \star}$ \\
\hline & $(-15.849)$ & $(-12.945)$ & $(-9.312)$ \\
\hline \multicolumn{4}{|l|}{ Compensation variables } \\
\hline \multirow{2}{*}{ Percent Incentive Compensation } & & $-.066^{\star \star \star}$ & $.252^{\star \star \star}$ \\
\hline & & $(-8.040)$ & $(9.745)$ \\
\hline \multirow{2}{*}{$\begin{array}{l}\text { Percent Incentive Compensa- } \\
\text { tion } \wedge 2\end{array}$} & & & $-.343^{\star \star \star}$ \\
\hline & & & $(-12.974)$ \\
\hline \multicolumn{4}{|l|}{ Model significance } \\
\hline R-Squared & $.025^{\star \star *}$ & $.029^{\star \star \star}$ & $.039^{\star \star \star}$ \\
\hline Adjusted R-Squared & $.024^{\star * *}$ & $.028^{\star \star *}$ & $.038^{\star \star \star}$ \\
\hline Change in R-Squared & & $.004^{\star \star \star}$ & $.010^{\star \star \star}$ \\
\hline
\end{tabular}

${ }^{*} p<.05$ level, ${ }^{* \star} p<.01$ level, ${ }^{\star * \star} p<.001$ level $n=18,540$

top line $=$ standardized beta coefficients (constant is unstandardized)

bottom line $=$ t-statistics (in parentheses) 
Table 4

4-year Cumulative Abnormal Returns

\begin{tabular}{|c|c|c|c|}
\hline & Model (1) & Model (2) & Model (3) \\
\hline \multirow{2}{*}{ Constant } & .030 & .129 & -.014 \\
\hline & $(.264)$ & $(1.148)$ & $(-.124)$ \\
\hline \multicolumn{4}{|l|}{ Control variables } \\
\hline \multirow{2}{*}{ Net Sales } & .018 & .022 & .017 \\
\hline & $(1.535)$ & $(1.892)$ & $(1.496)$ \\
\hline \multirow{2}{*}{ Number of Employees } & $.023^{*}$ & $.024^{*}$ & .021 \\
\hline & $(1.995)$ & $(2.083)$ & $(1.827)$ \\
\hline \multirow{2}{*}{ Total Compensation } & $-.131^{\star \star \star}$ & $-.110^{\star \star \star}$ & $-.080^{\star \star \star}$ \\
\hline & $(-16.460)$ & $(-13.325)$ & $(-9.382)$ \\
\hline \multicolumn{4}{|l|}{ Compensation variables } \\
\hline \multirow{2}{*}{ Percent Incentive Compensation } & & $-.072^{\star \star \star}$ & $.275^{\star \star \star}$ \\
\hline & & $(-8.794)$ & $(10.673)$ \\
\hline \multirow{2}{*}{$\begin{array}{l}\text { Percent Incentive Compensa- } \\
\text { tion ^ } 2\end{array}$} & & & $-.375^{\star \star \star}$ \\
\hline & & & $(-14.210)$ \\
\hline \multicolumn{4}{|l|}{ Model significance } \\
\hline R-Squared & $.027^{\star \star \star}$ & $.032^{\star \star \star}$ & $.044^{\star \star \star}$ \\
\hline Adjusted R-Squared & $.027^{\star \star \star}$ & $.031^{\star \star *}$ & $.043^{\star * *}$ \\
\hline Change in R-Squared & & $.005^{\star \star \star}$ & $.012^{* * *}$ \\
\hline
\end{tabular}

${ }^{\star} p<.05$ level, ${ }^{\star \star} p<.01$ level, ${ }^{* \star \star} p<.001$ level $n=18,540$

top line $=$ standardized beta coefficients (constant is unstandardized)

bottom line $=$ t-statistics (in parentheses) 
Table 5

5-year Cumulative Abnormal Returns

\begin{tabular}{|c|c|c|c|}
\hline & Model (1) & Model (2) & Model (3) \\
\hline \multirow{2}{*}{ Constant } & .008 & .123 & -.041 \\
\hline & $(.059)$ & $(.954)$ & $(-.319)$ \\
\hline \multicolumn{4}{|l|}{ Control variables } \\
\hline \multirow{2}{*}{ Net Sales } & .015 & .019 & .014 \\
\hline & $(1.284)$ & $(1.644)$ & $(1.246)$ \\
\hline \multirow{2}{*}{ Number of Employees } & .021 & $.022+$ & .019 \\
\hline & $(1.850)$ & (1.939) & $(1.682)$ \\
\hline \multirow{2}{*}{ Total Compensation } & $-.131^{\star \star \star}$ & $-.111^{\star \star \star}$ & $-.080^{\star \star \star}$ \\
\hline & $(-16.522)$ & $(-13.354)$ & $(-9.408)$ \\
\hline \multicolumn{4}{|l|}{ Compensation variables } \\
\hline \multirow{2}{*}{ Percent Incentive Compensation } & & $-.073^{\star \star \star}$ & $.274^{\star \star \star}$ \\
\hline & & $(-8.901)$ & $(10.653)$ \\
\hline \multirow{2}{*}{$\begin{array}{l}\text { Percent Incentive Compensa- } \\
\text { tion } \wedge 2\end{array}$} & & & $-.375^{\star \star \star}$ \\
\hline & & & $(-14.224)$ \\
\hline \multicolumn{4}{|l|}{ Model significance } \\
\hline R-Squared & $.028^{\star \star \star}$ & $.033^{\star \star \star}$ & $.045^{\star \star \star}$ \\
\hline Adjusted R-Squared & $.028^{\star \star \star}$ & $.032^{\star \star \star}$ & $.044^{\star \star *}$ \\
\hline Change in R-Squared & & $.005^{\star \star \star}$ & $.012^{\star \star \star}$ \\
\hline
\end{tabular}

* $p<.05$ level, ${ }^{* *} p<.01$ level, ${ }^{* \star *} p<.001$ level $n=18,540$

top line $=$ standardized beta coefficients (constant is unstandardized)

bottom line $=$ t-statistics (in parentheses)

\section{DISCUSSION AND IMPLICATIONS}

Pierce and Aguinis (2013) introduce a meta-theoretical principle called toomuch-of-a-good-thing effect (TMGT effect). They suggest antecedent variables widely accepted as leading to desirable consequences sometimes actually lead to negative outcomes. The authors posit that, due to the TMGT effect, seemingly monotonic positive relations reach context-specific inflection points after which relations turn asymptotic and often negative, resulting in an overall pattern of curvilinearity. The authors offer examples in key areas such as organization behavior (e.g. leader- 
ship, personality), human resource management (e.g. job design, personnel selection), entrepreneurship (e.g. new venture planning, firm growth rate), and strategic management (e.g. diversification, organizational slack).

We believe our results fit well with the implications of the TMGT effect. Specifically, the results indicate moderate levels of incentive-based compensation of CEOs are optimal for overall firm performance. CEOs in Q3 (CEOs receiving $35-52 \%$ incentive-based compensation) consistently outperform other CEOs. Most interestingly, the CEOs in Q3 significantly outperform those in Q4 and Q5, meaning incentive-based compensation is good to a point but there is a TMGT effect. This finding is robust across each of the first five years of financial performance after the announcement of stock option grants. The implication of our findings is that basing more of an executive's total compensation package on firm performance is associated with higher abnormal returns to a point, but beyond that point diminishing returns occur. Specifically, the peak CAR occurs for CEOs given $42 \%$ incentive-based compensation. Our results lead us to believe that agency theory does not tell the whole story. At some point, it becomes detrimental for a firm to give an executive more performance-based pay relative to total pay.

This study provides useful insights for both future research and managerial practice. From a risk perspective, these results are consistent with those of Wright et al. (1996). They found insider ownership to have a nonlinear (concave) relationship with firm risk-taking. We agree that aligning the risk propensities of CEOs and shareholders is the key for increased performance, and our study provides evidence of the effect of compensation package on that performance.

Prospect theory helps explain the misalignment of incentives between the $\mathrm{CEO}$ and shareholders. Executives possessing options in the money are more likely to adopt a strategy that is too defensive while those out of the money are likely to become too risky. Executives also shift their reference points to the current stock price, meaning every rise or fall in the stock price feels like a real financial gain or loss to the executive. Obviously, so much focus on the stock price gives the executive incentive to increase that value at all costs, maybe even engaging in unethical behavior in the process. Another potential explanation not explored in this paper is the role of prior wealth of the CEO. If a CEO is very wealthy prior to his/her current employment, he/she may be more willing to assume risk because this income is expendable. These explanations in light of prospect theory certainly have face validity but need to be corroborated, perhaps through additional qualitative research.

Agency theory has long served as the basis for executive compensation research. The application of agency theory, however, has produced mixed results in 
the literature. Dalton et al. (2003) suggested agency theory alone is insufficient, stating that a new lens must be applied. We agree with their suggestion and provide convincing evidence that a positive linear relationship assumption does not tell the whole story in terms of proper structuring of executive compensation contracts. Certainly, some amount of the CEOs compensation should be tied to the performance of the firm in order to properly align his/her interests with those of the shareholders. However, past some point (around $42 \%$ for CEOs in this study), more relative incentive-based compensation is associated with poorer firm performance.

We have suggested the insufficiency of agency theory is due to its reliance on certain assumptions of utility theory. We offer prospect theory as an alternative to utility theory and apply it to the executive compensation context. Prospect theory provides greater insight into the link between incentive-based compensation and CEO risk preference. This insight can also be useful in explaining the appropriate levels of incentives varies by CEO. Our findings support the use of prospect theory to develop a stronger understanding of executive compensation, and help set the stage for future research in this arena.

A potential managerial implication of our results is that boards of directors need better communication with their CEOs. Board members could simply inquire of the CEO's preferences for incentive compensation rather than trying to assume their preferences. The purpose of an incentive-based compensation plan is to properly motivate the executive. Our results suggest the amount of incentive-based compensation should be a sizable percentage (35-52\%) of total compensation, but what properly motivates one CEO may not work for another. CEOs and boards should work together to create a compensation package that provides the stability of guaranteed salary and the performance incentive of stock options. This can lead to a situation that promotes better performance at both the executive and firm level.

\section{LIMITATIONS AND FUTURE RESEARCH}

Our results suggest a moderate level of performance-based compensation package is most appropriate, particularly when based on the CEO's specific risk preferences. Future research in this arena should incorporate qualitative measures to support our empirical findings. This qualitative research could include and this could include detailed interviews with CEOs. Such interviews may offer more evidence as to the levels of risk seeking and risk aversion among executives. Additional research should also examine contingency factors where this relationship may be stronger or weaker, such as firm size, firm age, and industry. Our study examined only the 
overall sample of CEOs, but future studies might examine mean differences between subsets of CEOs. These studies should employ a variety of performance measures to determine if the nonlinear relationship is robust across accounting performance measures as well as market measures. A more thorough understanding of executive compensation can lead to better relationships between CEOs and their boards.

\section{CONCLUSION}

In conclusion, this paper demonstrates there is a relationship between incentive-based CEO compensation and the actual performance of the firm. While the variance explained may appear to be a rather small number, the results of this small number when examined on the scale of a large corporation are immense. Executive compensation can be very complex and our results shed some additional light on this critically important topic. An appropriate compensation package is needed to attract the necessary executive talent to best deliver positive organizational outcomes.

By utilizing prospect theory, this paper has demonstrated there is a non-linear (concave) relationship between incentive-based CEO compensation and firm performance. As margins continue to shrink and competition continues to increase, the optimal CEO compensation package, should be an area of increased concern. If firms, by properly structuring their CEO compensation plans, can increase performance then this research can support proper decision making in regards to that compensation package. Therefore, we suggest that our findings provide value for both academic researchers and business practitioners, and add a new piece to our understanding of the executive compensation puzzle.

\section{REFERENCES}

Bae, B. \& Sami, H. (2005). The effect of potential environmental liabilities on earnings response coefficients. Journal of Accounting, Auditing \& Finance, 20, 4370.

Brunnermeir, M. (2004). Learning to reoptimize consumption at new income levels: A rationale for prospect theory. Journal of the European Economic Association, 2, 98-114.

Buck, T., Bruce, A., Main, B., \& Udueni, H. (2003). Long-term incentive plans, executive pay and UK company performance. The Journal of Management Studies, 40, 1709-1727.

Chaudhri, V. (2003). Executive compensation: Understanding the issues. Australian Economic Review, 36, 300-305. 
Dalton, D., Daly, C., Certo, T., \& Roengpitya, R. (2003). Meta-analyses of financial performance and equity: Fusion or confusion? Academy of Management Journal, 46, 13-26.

Ding, D., Charoenwong, C., \& Seetoh, R. (2004). Prospect theory, analyst forecasts, and stock returns. Journal of Multinational Financial Management, 14, 425442.

Eisenhardt, K. (1989). Agency theory: An assessment and review. Academy of Management Review, 14, 57-74.

Eisenmann, T. (2002). The effects of CEO equity ownership and firm diversification on risk taking. Strategic Management Journal, 23, 513-534.

Hambrick, D. \& Jackson, E. (2000). Outside directors with a stake: The linchpin in improving governance. California Management Review, 42, 108-124.

Jensen, M. \& Meckling, W. (1976). Theory of the firm: Managerial behavior, agency costs and ownership structure. Journal of Financial Economics, 3, 305-360.

Jensen, M. \& Murphy, K. (1990). Performance pay and top management incentives. Journal of Political Economy, 98, 225-264.

Kahneman, D. \& Tversky, A. (1979). Prospect theory: An analysis of decision under risk. Econometrica, 47, 263-291.

Kim, J. (2004). Executive compensation contracts: Change in the pay-performance sensitivity within firms. Journal of American Academy of Business, 4, 449-454.

Levy, H. \& Levy, M. (2004). Experimental test of the prospect theory value function: A stochastic dominance approach. Organizational Behavior and Human Decision Processes, 89, 1058-1081.

McConnell, J. \& Servaes, H. (1990). Additional evidence on equity ownership and corporate value. Journal of Financial Economics, 27, 595-612.

McGuire, J. \& Matta, E. (2003). CEO stock options: The silent dimension of ownership. Academy of Management Journal, 46, 255-265.

Mehran, H. (1995). Executive compensation structure, ownership, and firm performance. Journal of Financial Economics, 38, 163-184.

Mengistae, T. \& Lixin, C. (2004). Agency theory and executive compensation: The case of Chinese state-owned enterprises. Journal of Labor Economics, 22, 615637.

Morck, R., Shleifer, A., \& Vishny, R. (1988). Management ownership and market valuation: An empirical analysis. Journal of Financial Economics, 20, 293-315.

Noorderhaven, N.G. (1992). The problem of contract enforcement in economic organization theory. Organization Studies, 13(2), 229. 
Pierce, J. \& Aguinis, H. (2013). The too-much-of-a-good-thing effect in management. Journal of Management, 39, 313-338.

Shen, C. \& Chih, H. (2005). Investor protection, prospect theory, and earnings management: An international comparison of the banking industry. Journal of Banking \& Finance, 29, 2675-2697.

Sundaramurthy, C., Rhoades, D., \& Rechner, P. (2005). A meta-analysis of the effects of executive and institutional ownership on firm performance. Journal of Managerial Issues, 17, 494-510.

Tsetsekos, G. \& DeFusco, R. (1990). Portfolio performance, managerial ownership, and the size effect. Journal of Portfolio Management, 16, 33-39.

Wright, P., Ferris, S., Sarin, A., \& Awasthi, V. (1996). Impact of corporate insider, blockholder, and institutional equity ownership on firm risk-taking. Academy of Management Journal, 39, 441-458.

Wright, P., Kroll, M. \& Davis, P. (2007). The influences of the chief executive officer's stock and option ownership on firm risk taking: An examination of resource allocation choices. Academy of Strategic Management Journal, 6, 47-68.

\section{BIOGRAPHICAL SKETCH OF AUTHORS}

Joshua R. Aaron is an Assistant Professor in the Management \& Marketing Department in the Jennings A. Jones College of Business at Middle Tennessee State University. He currently serves as the Treasurer of the national Small Business Institute ${ }^{\circledR}$. Dr. Aaron's research and expertise focuses on strategic management, strategic planning, corporate reputation and small business strategy.

Michael L. Harris is an Associate Professor and Chair of the Department of Management at East Carolina University. He currently served as the Vice-President of the National Small Business Institute ${ }^{\circledR}$. Dr. Harris’ research interests include small business strategy, entrepreneurial attitudes and intentions, and entrepreneurship education.

William C. McDowell is a Full Professor and the Wright Travel Chair in Entrepreneurship in the Jennings A. Jones College of Business at Middle Tennessee State University. He currently serves as the President-Elect of the national Small Business Institute ${ }^{\circledR}$. Dr. McDowell's research and expertise focuses on small business and entrepreneurship.

Brandon N. Cline is the BancorpSouth Professor of Finance in the Department of Finance and Economics at Mississippi State University. Dr. Cline's research focuses on insider trading, executive compensation, equity offerings, and corporate governance. 